\title{
KNOWLEDGE CREATION FROM THE PERSPECTIVE OF THE SUPPLY CHAIN. THE ROLE OF ICT ${ }^{1}$
}

\author{
ANDREA KÖ $^{1}$ - RÉKA VAS ${ }^{2}$ - TIBOR KOVÁCS ${ }^{3}$ - ILDIKÓ SZABÓ ${ }^{4}$ \\ ${ }^{1}$ Department of Information Systems, Corvinus University of Budapest, Hugary \\ Email: andrea.ko@uni-corvinus.hu \\ ${ }^{2}$ Department of Information Systems, Corvinus University of Budapest, Hugary \\ Email: reka.vas@uni-corvinus.hu \\ ${ }^{3}$ Department of Information Systems, Corvinus University of Budapest, Hugary \\ Email: tibor.kovacs@uni-corvinus.hu \\ ${ }^{4}$ Department of Information Systems, Corvinus University of Budapest, Hugary \\ Email: ildiko.szabo2@uni-corvinus.hu
}

Technological innovations are inclining the world of business to restructure actual business processes at the threshold of the fourth industrial revolution. These circumstances create knowledge-intensive organizational, collective and personal learning environments in which ICT tools play a critical role. This paper investigates knowledge creation patterns inherent in the supply chain of companies that operate in a networked environment in the Székesfehérvár region of Hungary. ICT solutions applied in knowledge creation and collaboration with suppliers and customers in the supply chain were studied in this research. One of the main contributions of the paper is the study of knowledge creation patterns in three dimensions: the Socialization - Externalization - Combination - Internalization (SECI) framework, supply chain processes and ICT solutions, which is a unique approach compared with the frameworks from the relevant literature.

Keywords: knowledge creation, supply chain, ICT solution, SECI model

JEL codes: D83

The publication was written within the Széchenyi 2020 programme framework (EFOP-3.6.116-2016-00013) under the European Union project titled: "Institutional developments for intelligent specialization at the Székesfehérvár Campus of Corvinus University of Budapest". 


\section{INTRODUCTION}

This paper investigates the role of Information and Communication Technologies (ICTs) in supporting knowledge creation patterns of companies operating in the Székesfehérvár region of Hungary. Knowledge management and knowledge functions have an extensive literature with challenging research questions. Focusing on knowledge creation, one of the most decisive theories is the Socialization - Externalization - Combination - Internalization (SECI) model by Nonaka and Takeuchi (1995), which was validated by analysing knowledge management practices of Japanese companies. The authors distinguished two categories of knowledge tacit and explicit - and described possible ways of conversions between these categories. As Polanyi (1967) described it, tacit knowledge or personal knowledge is related to skills, expertise, experimental learning and know-how. This category of knowledge can barely be described or indeed not at all in semantic languages (e.g. knowledge of walking, or bicycle riding). In contrast, explicit knowledge can be formalized, or in other words it can be described in semantic languages. Knowledge creation has a key role in organizational learning, which provides great potential for improving organizational outcomes, such as competitive advantage (Lopez-Nicolas - Soto-Acosta 2010; Templeton et al. 2002). Digital transformation draws attention to the opportunities provided by technological innovations, which includes the renewing of knowledge creation as well as sharing.

We analysed the role of technology in knowledge management with a special focus on knowledge creation (Ko et al. 2008; Gillani - Ko 2016). The literature on the role of ICT solutions in knowledge management (KM) is extensive, however, the majority of the papers discuss only specific knowledge management systems (KMS) per se, or topics in relation to knowledge management functions (Nonaka - Lewin 1994; Uriarte 2008). There are papers that analyse the technological aspects of knowledge creation, but they do not sufficiently emphasize the operational aspects, such as the connection of KM systems with business processes in the supply chain (Lopez-Nicolas - Soto-Acosta 2010). Supply chain management (SCM) has a decisive role in company operations with numerous links to knowledge management. Dyer and Nobeoka (2000) studied knowledgesharing routines developed by Toyota and its suppliers. Wagner and Buko (2005) discussed the specialties of knowledge sharing with customers, suppliers and research institutions. Bessant et al. (2003) studied six UK supply chains at various stages of implementing supply chain learning, and finally, Halley and Beaulieu (2005) analysed the links between supply chain and knowledge management practices. While researchers agree that knowledge creation has a critical role in SCM, only a few studies have analysed the ICT related aspects of this process and there is a lack of empirical demonstration. 
The aim of our research is to bridge this gap by focusing on identifying knowledge creation patterns in supply chains that operate in a networked environment and on the role of ICT solutions in these processes. The goal is to increase understanding of how knowledge is created in supply chains and what the key ICT solutions and their role in these processes are.

This paper will be structured as follows. First the knowledge creation challenges are outlined; then the literature review is discussed. The knowledge creation framework is presented in section three. Research objectives, methods and the research model are detailed in section four. The empirical results are discussed in section five, and a conclusion is drawn in section six.

\section{LITERATURE REVIEW - THE BACKGROUND OF THE RESEARCH}

Technological innovations are inclining the world of business to restructure actual business processes at the threshold of the fourth industrial revolution. In this knowledge-intensive environment where continuous organizational, collective and/or personal learning has never been more important, ICT inevitably plays a critical role in supporting both general business processes and knowledge management (KM) specific activities. The literature review identified papers that move towards an understanding of the overall importance of ICTs in knowledge management (Subashini et al. 2012; Vipinkumar et al. 2013). In these papers, the focus is not on identifying which types of ICT tools should be applied, but rather on whether the use of ICT has any impact on the effectiveness of KM activities. Okunoye and Karsten (2002) even managed to prove that information technology infrastructure plays a crucial role in knowledge management by enabling efficient communication, easy knowledge transfer, faster knowledge creation and organizational memory building. Another branch of theories suggests that the ICT support of each knowledge function should be studied separately. Theories in this branch can be divided into two groups depending on their assumptions on what kind of ICT tools should be considered. On one extreme, there are theories that suggest that only KM systems can support knowledge functions. Under Jashapara's (2004: 91) theory, KM systems are grouped according to "their ability to perform a knowledge function such as organizing, capturing, analysing, storing and sharing knowledge". Uriartre (2008) considers knowledge creation and capture; knowledge sharing and enrichment; information storage and retrieval, as well as knowledge dissemination as the elements of KM systems. At the other extreme, researchers investigate the knowledge management supporting function of both KM systems and more general ICT tools. Maier (2007) identified the following KM tasks and facilitating ICT tools: 
- Knowledge identification: the detection and visualization of organizational knowledge assets. This function can be enhanced by knowledge modelling and mapping technologies.

- Knowledge acquisition: the acquisition of new knowledge from outside of the company by using human resource management (HRM) techniques (such as enhancing the engagement of experts or emphasizing the importance of knowledge-related events) or, e.g., accessing documented knowledge via online databases.

- Knowledge creation: the creation of new knowledge (skills, ideas, processes, competencies) within the organization. This is regarded as a creative task, which is supported by the relevant functions of groupware systems.

- Knowledge organization: it links created knowledge elements with each other. This can be visualized by knowledge mapping tools.

- Knowledge publication: it involves the codification of knowledge in various forms for the purpose of storage. This task prepares knowledge for distribution. Content management systems and web publishing systems can facilitate the execution of this task.

- Knowledge distribution or sharing: the circulation of knowledge among stakeholders via knowledge push technologies - such as e-learning platforms, or learning management systems.

- Knowledge search and retrieval: the delivery of relevant knowledge to knowledge seekers by using recommendation systems or search engines built on knowledge graphs.

- Knowledge application: the use of detected, codified, published and distributed knowledge to achieve organizational or personal aims. Every type of KM technology via search, retrieval and visualization systems supports this by translating knowledge into the actual application.

- Knowledge evolution: the improvement of existing knowledge. Programme functions such as posting comments, checking links or document expiration dates; or workflow/quality management solutions can enhance this activity.

- Knowledge deletion and archiving: the management or sales of irrelevant or outdated knowledge. These tasks do not require any special ICT functions.

- Collaboration: it requires direct interaction of partners during knowledge transfer and application. Interactive knowledge management, groupware systems, synchronous communication and collaboration tools support this task.

The literature survey also demonstrates that knowledge transfer (including both knowledge donation and receiving) is the most extensively studied aspect either at an organizational or an inter-organizational level (Hendricks 1999; LeeLee 2000; Corso - Paolucci 2001; Garavelli et al. 2002). One example could be a 
study by Nelissen et al. (2008) which - focusing on organizational teams - found that ICT plays a dominant role in sharing knowledge in relatively large, dispersed organizational teams, while it has a crucial but not a dominant role in the case of small teams (where face to face communication seems the most important).

Insights gained from the study on how IT supports organizational knowledge sharing processes have been reapplied in analysing the same processes at an inter-organizational level, in networks of companies. A recent paper surveying the role of information systems in transferring knowledge in internal networks of multinational companies (MNC) by Szász et al. (2017) argued that there is a difference in how knowledge sending and knowledge receiving companies perceive the role of IT in the transfer process. Neither parties question the necessity of information systems in knowledge transfer. At the same time knowledge sending plants of MNCs find information systems less supportive, while most knowledge receivers heavily rely on and trust information systems in accessing the required knowledge.

The influence of the adoption and use of ICT on organizational learning using the SECI model as a reference for knowledge creation was studied by LopezNicolas and Soto-Acosta (2010). They analysed ICT use from three different orientations: informative, communicative and workflow on a sample of around 300 Spanish SMEs. Their results showed that ICT has a significant positive influence on the four processes for creating knowledge. ICT oriented to communication and workflow has a significant positive impact on knowledge creation processes, except in the case of socialization process, while ICT use for information does not influence any of the processes for creating knowledge and OL.

Another group of studies make a move forward and investigate which types of information systems are applied in knowledge management processes of company networks (Swan et al. 1999; Carlsson 2003; Spence 2005). Retzer (2010) examined the nature of knowledge transfer among key organisations in New Zealand to identify practical implications on how specific ICT tools can support and enhance knowledge sharing in networks. The major contribution provided by this work was that options for ICT support of knowledge transfer at the individual, group and inter-organisational level were all presented providing a comprehensive overview of the field. Retzer also analysed the role of social technologies in knowledge transfer, which was a new tool at that time.

Papers studying the link between knowledge and supply chain management highlighted that not only ICT tools specifically developed for offering knowledge management related services play a role in enhancing knowledge transfer and creation, but operational systems as well. Stock and Boyer (2009) found that several researchers (Mentzer et al. 2001; Choon Tan 2001; Cooper et al. 1997) emphasize the management philosophy aspect of SCM instead of its 
operational side. Supply chain management processes provide opportunities to seize the knowledge management aspects of SCM. The definition provided by Supply Chain Management Professionals highlights the importance of coordination and collaboration between partners during supply chain activities that are at the focus of our study: "SCM encompasses the planning and management of all activities involved in sourcing and procurement, conversion, and all logistics management activities. Importantly, it also includes coordination and collaboration with channel partners, which can be suppliers, intermediaries, third-party service providers, and customers" (Stock - Boyer 2009). A literature review presented by Marra et al. (2011) extensively examined the role of knowledge management in SCM. Beyond general SCM activities, Knowledge Supply Chains can also nourish business processes with knowledge and contribute to developing new products and innovations. Open innovation and new product development processes provide a context for investigating their role in knowledge transfers and collaboration. Five knowledge aspects of open collaboration were identified: type of knowledge supply (open/closed), type of knowledge interaction (static/ dynamic), focus of control (centralized, decentralized), governance (hierarchical/ market-based) or sourcing mode (financial/non-financial). A new methodology, called Collaborative Knowledge Schema was elaborated to map out the knowledge supplies and assess their criticalities from a business process perspective based mostly on literature reviews due to the lack of open innovation practices (Bellantuono et al. 2013). The extended methodology was connected to the open innovation approach. Innovation practices were analysed based on these results (Bellantuono et al. 2013). The growing number of papers on innovation development in supply chains also proves that analyzing knowledge creation patterns in the supply chain is of relevance.

\section{KNOWLEDGE CREATION FRAMEWORK}

In this paper, knowledge creation is defined according to the Socialization-Externalization-Combination-Internalization (SECI) model of Nonaka and Takeuchi (1995). Accordingly, organizational knowledge creation is a continuous and dynamic interaction between tacit and explicit knowledge. As a result of these interactions four basic types of knowledge conversion were distinguished (Nonaka - Lewin 1994):

- Socialization: from tacit to tacit knowledge

- Externalization: from tacit to explicit knowledge

- Combination: from explicit to explicit knowledge

- Internalization: from explicit to tacit knowledge. 
Socialization is described as a process of sharing experiences. It results in such tacit knowledge as shared intellectual models and technical skills. Tacit knowledge can be acquired without knowing any words or languages, principally through experiences. Externalization is a knowledge creating process that converts tacit knowledge into explicit knowledge that appears as metaphors, analogies, concepts, hypothesis and models. The most often used method of formulating a concept is the combination of induction and deduction. In this sense externalization often results in the creation of metaphors and/or analogies. Combination includes the synthesis of the different forms of explicit knowledge. It is a process of building a knowledge system from concepts. Internalization is the process of converting explicit knowledge to tacit knowledge. Internalization is enclosed by practical learning or learning by doing. When experiences infiltrate the hidden knowledge bases of individuals as shared intellectual models or technical know-how, they turn into substantial organizational tools due to socialization, externalization and combination. These four processes (phases) are cyclically repeated in companies during knowledge creation. This is not simply a cyclical process but an ascendant spiral process: current organizational knowledge is combined with new information in a given context to create new knowledge that can be utilized both on an individual or collective level (Figure 1). In this way knowledge of all affected users is expanded, in other words they learn. Within an enterprise there are many knowledge spirals that are likely to overlap one another.

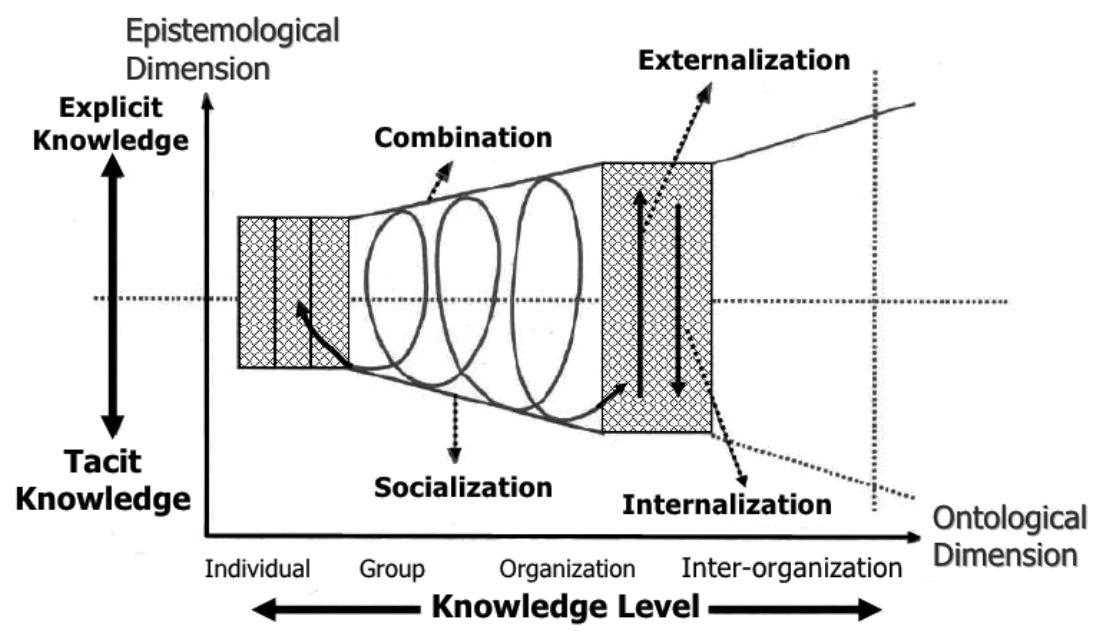

Figure 1. Spiral of organizational knowledge creation

Source: Nonaka - Takeuchi (1995: 73) 


\section{RESEARCH OBJECTIVES AND METHODS}

As the literature has revealed, ICT has an impact on the effectiveness of knowledge management activities in general and also on knowledge creation specifically. While a major group of papers analyzed the impact of specific knowledge management technologies in knowledge creation and agree that knowledge creation is an integral part of SCM, only a few of the studies analyzed the role of supply chain specific ICT solutions in developing or enhancing the development of new knowledge. Our research focuses on identifying typical knowledge creation patterns of supply chains operating in a networked environment. More specifically, the goal of this research is to understand and discover how knowledge is created in supply chains, what the key applied ICT solutions are, and what their role in this process is. Accordingly, the following research questions were formulated:

1) What are the knowledge creation patterns in a supply chain (in the Székesfehérvár Region of Hungary)?

2) What are the main ICT solutions applied in the supply chain and what is their role in knowledge creation and collaboration with suppliers and customers?

\subsection{Research Methods}

The scope of this research surrounds ICT support for the knowledge creation function. A combination of qualitative and quantitative methods was applied in this paper. In the literature review, an overview of 50+ research projects on the ICT support of knowledge functions was provided. Although a considerable number of studies on the application of ICT tools in knowledge sharing and transfer have reported promising findings, no evidence is provided concerning the role of ICT tools in knowledge creation. In order to address the research questions the most decisive model of the knowledge creation field - SECI by Nonaka and Takeuchi (1995) was adopted in the study. The literature review showed that not only the supporting role of knowledge management systems, but the role of supply chain management systems in knowledge creation should be studied. Only a limited number of researchers connect knowledge creation to ICT in the supply chain (Samuel et al. 2011; Garcia-Muniz - Vicente 2014; Ko et al. 2010). In the next phase the conceptual model of the research was set up, which was followed by the development of a structured questionnaire that provided the bases for collecting data from selected companies for validation purposes. 


\subsection{Research model}

Lopez-Nicolas and Soto-Acosta (2010) scrutinized the link between the SECI model and ICT tools in organizational knowledge creation processes. Their model focused on ICT adoption and three different orientations of ICT use: informative, communicative and workflow. The scope of ICT tools in their model was tight, and they did not incorporate business processes from the supply chain to their model.

Samuel et al. (2011) studied how the SECI model could facilitate supply chain management processes without any information on applied ICT tools. These authors emphasized certain parts of our research, hence these approaches were specified and extended with new aspects within the framework of our research. Corporate networking presents the context of our approach, hence those supply chain management processes were selected that require cooperation between companies at a high level. Collaborative ICT tools were chosen that can manage these endeavours in an efficient manner. The SECI model reflects knowledge creation well, as has been stated many times in the related literature. The following model was created based on these guidelines. The conceptual model in our approach has three main dimensions: a) knowledge creation patterns based on the SECI model b) a supply chain view described by five key processes, and c) ICT solutions (Figure 2).

The following supply chain processes that are reliant on knowledge sharing and creation were studied in this research:

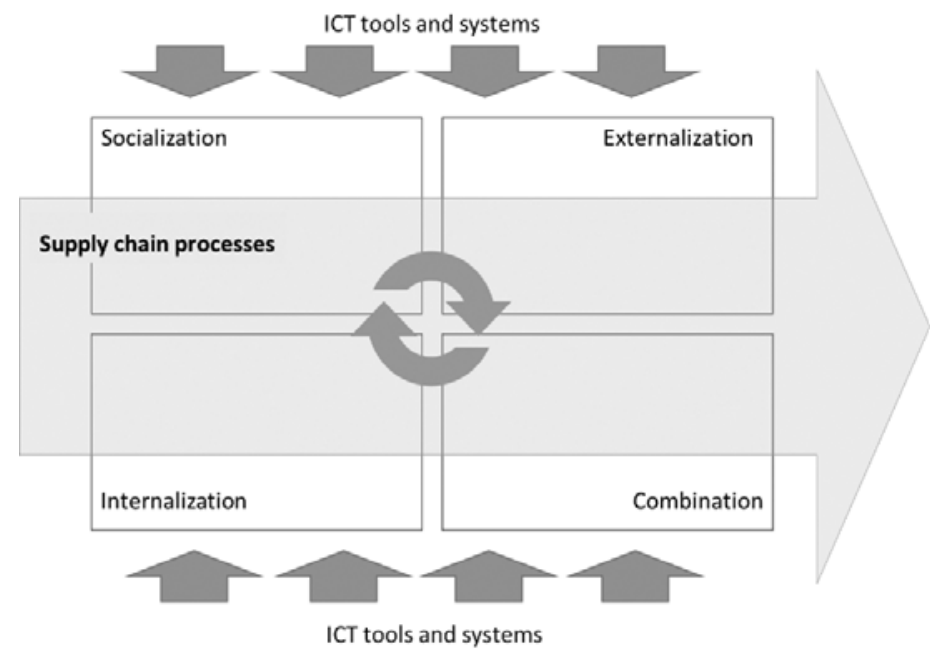

Figure 2. Research model

Source: authors. 
1) solving problems in day-to-day operations

2) developing new products and services

3) technology transfer of new products or processes to suppliers or customers

4) reviewing supplier performance

5) exploring new business opportunities.

The third dimension of the conceptual model consists of a series of ICT solutions and investigates their usage patterns (the frequency and mode of their application in SECI).

Table 1 provides a summary of the identified activities of the key supply chain processes that later provided the basis for the questionnaire development.

The third dimension includes ICT solutions and application patterns (the mode and frequency of use in SECI). In order to be able to compare results, ICT tools and systems supporting key supply chain processes are also included

Table 1. Detailed activities in key supply chain processes

\begin{tabular}{|c|c|c|c|c|c|c|}
\hline \multirow{2}{*}{$\begin{array}{l}\text { Key supply } \\
\text { chain processes } \\
\text { Solving prob- } \\
\text { lems as part of } \\
\text { the day-to-day } \\
\text { operation }\end{array}$} & \multicolumn{6}{|c|}{ Detailed activities in key supply chain processes } \\
\hline & $\begin{array}{l}\text { recognis- } \\
\text { ing and } \\
\text { recording } \\
\text { problems }\end{array}$ & $\begin{array}{l}\text { joint } \\
\text { problem- } \\
\text { solving } \\
\text { meetings, } \\
\text { brainstorm- } \\
\text { ing }\end{array}$ & $\begin{array}{l}\text { formal, } \\
\text { structured } \\
\text { problem- } \\
\text { solving } \\
\text { activities }\end{array}$ & $\begin{array}{l}\text { document- } \\
\text { ing the } \\
\text { results of } \\
\text { problem- } \\
\text { solving }\end{array}$ & $\begin{array}{l}\text { sharing the } \\
\text { problem- } \\
\text { solving } \\
\text { results } \\
\text { within the } \\
\text { firm }\end{array}$ & $\begin{array}{l}\text { sharing the } \\
\text { problem- } \\
\text { solving } \\
\text { results with } \\
\text { external } \\
\text { partners }\end{array}$ \\
\hline $\begin{array}{l}\text { Developing } \\
\text { new products } \\
\text { and services }\end{array}$ & $\begin{array}{l}\text { prepara- } \\
\text { tion of new } \\
\text { product de- } \\
\text { velopment } \\
\text { projects }\end{array}$ & $\begin{array}{l}\text { launch } \\
\text { of new } \\
\text { product de- } \\
\text { velopment } \\
\text { projects }\end{array}$ & $\begin{array}{l}\text { joint } \\
\text { project } \\
\text { meetings }\end{array}$ & $\begin{array}{l}\text { joint trials } \\
\text { and test } \\
\text { runs }\end{array}$ & $\begin{array}{l}\text { approval } \\
\text { of new } \\
\text { product } \\
\text { or service } \\
\text { specifica- } \\
\text { tions }\end{array}$ & \\
\hline $\begin{array}{l}\text { Technology } \\
\text { transfer to } \\
\text { suppliers or } \\
\text { customers }\end{array}$ & $\begin{array}{l}\text { prepara- } \\
\text { tion of } \\
\text { technology } \\
\text { transfer } \\
\text { projects }\end{array}$ & $\begin{array}{l}\text { launch of } \\
\text { technology } \\
\text { transfer } \\
\text { projects }\end{array}$ & $\begin{array}{l}\text { joint } \\
\text { project } \\
\text { meetings }\end{array}$ & $\begin{array}{l}\text { joint trials } \\
\text { and test } \\
\text { runs }\end{array}$ & $\begin{array}{l}\text { approval } \\
\text { of new } \\
\text { product } \\
\text { or service } \\
\text { specifica- } \\
\text { tions }\end{array}$ & \\
\hline $\begin{array}{l}\text { Reviewing sup- } \\
\text { plier perform- } \\
\text { ance }\end{array}$ & \begin{tabular}{|l} 
analysis of \\
supplier \\
perform- \\
ance \\
\end{tabular} & $\begin{array}{l}\text { review of } \\
\text { supplier } \\
\text { perform- } \\
\text { ance } \\
\end{array}$ & $\begin{array}{l}\text { joint data } \\
\text { analysis }\end{array}$ & $\begin{array}{l}\text { joint action } \\
\text { lists }\end{array}$ & $\begin{array}{l}\text { develop- } \\
\text { ment of } \\
\text { business } \\
\text { processes }\end{array}$ & $\begin{array}{l}\text { documen- } \\
\text { tation of } \\
\text { business } \\
\text { processes }\end{array}$ \\
\hline $\begin{array}{l}\text { Exploring new } \\
\text { business } \\
\text { opportunities }\end{array}$ & $\begin{array}{l}\text { joint } \\
\text { preparation } \\
\text { for new } \\
\text { business } \\
\text { opportuni- } \\
\text { ties }\end{array}$ & $\begin{array}{l}\text { joint prepa- } \\
\text { ration of } \\
\text { proposals } \\
\text { and tenders }\end{array}$ & $\begin{array}{l}\text { joint pres- } \\
\text { entation of } \\
\text { proposals } \\
\text { and tenders }\end{array}$ & $\begin{array}{l}\text { approval of } \\
\text { contracts } \\
\text { and specifi- } \\
\text { cations }\end{array}$ & & \\
\hline
\end{tabular}

Source: authors 
in the current research that were applied by Samuel et al. (2011). Accordingly, the tools analyzed are the following: meetings in person (this tool has been kept to describe the "no ICT used" option), telephone calls, tele-conferences, videoconferences, sharing computer screens, shared drives, email, workflow systems, document management systems, integrated systems (SAP, EDI) and web applications. These ICT solutions combined with activities in key supply chain processes describe certain knowledge creation patterns, socialization, externalization, combination and internalization. In this way the research model can identify the decisive knowledge creation patterns in certain supply chain processes, while information on the applied ICT tool is also provided.

\subsection{The questionnaire}

The questionnaire contained 21 questions (some of them were longer questions with sub-questions), which were classified in the following way: questions on general company information; questions (a matrix of questions) on the networking of 33 companies in the Székesfehérvár region; questions on knowledge creation practices in the supply chain (see Table 2 and the explanation in the previous section); questions on the types of ICT tools and systems applied in these companies; and questions on collaboration with individual customers.

Due to the complexity of the questionnaire, data were collected in the form of interviews with the selected companies in the region. The key part of the questionnaire consists of questions on knowledge creation practices in the supply chain. Table 2 shows the questionnaire in the case of processes related to "solving day-to-day business problems", while Table 3 is about the mapping out of the research model's three dimensions (knowledge creation patterns, supply chain processes and ICT solutions) for the questionnaire in the case of "solving day-today business problems" process. The first column shows the activities of "solving day-to-day business problems" processes (as detailed in Table 1) and the second row is the ICT solutions which can be applied in certain activities. We asked the respondents to highlight the typical ICT solution used in a certain activity. These answers were processed with the application of Table 3, which maps the answers to the knowledge creation patterns.

Mapping is based on the literature (Samuel et al. 2011; Nonaka - Takeuchi 1995) and discussion by experts. Knowledge creation patterns are based on the SECI model and consist of four types as detailed in Section 3: socialization, externalization, combination and internalization (denoted in Table 3 with S, E, C and I). This mapping allowed us to analyze the knowledge creation practices of the studied companies. 
Table 2. Questions on knowledge creation practices related to the process of "solving day-to-day business problems" in the supply chain

\begin{tabular}{l} 
How do you work together with your business partners in solving day-to-day business problems \\
\hline \\
\hline
\end{tabular}

Source: authors

\section{THE CASES}

Companies selected for study are predominantly suppliers of the automotive industry, suppliers of electronics manufacturing and IT related service provider industries in the Székesfehérvár region. Questions on knowledge creation patterns ask specific questions about how the company works together with their suppliers and customers during the aforementioned five supply chain processes; how often these processes are executed and what kind of IT enabled communication processes are used to support these activities. In order to further explore the relationship between knowledge creation processes and ICT systems, specific subprocesses of the five key supply chain processes have been specified and linked to the SECI model, as detailed in Table 1. The role of sub-process in the SECI model is not only defined by the sub-process itself, but also by what kind of ICT tool is applied to support that activity. For example, the "joint problem-solving, brainstorming" process is defined as "Socialization" only if in-person meetings or telephone-calls are performed. However, if shared drives or workflow systems 
Table 3. Knowledge creation practices patterns for "solving day-to-day business problems" process in the supply chain

\begin{tabular}{|c|c|c|c|c|c|c|c|c|}
\hline \multicolumn{9}{|c|}{$\begin{array}{l}\text { How do you cooperate with your business partners in solving day-to-day business problems } \\
\text { and what type of tools do you use? }\end{array}$} \\
\hline & 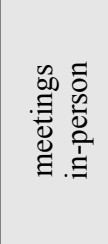 & 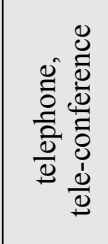 & 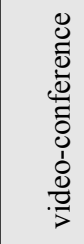 & 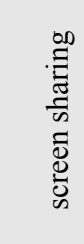 & 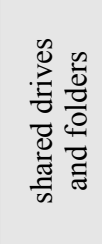 & 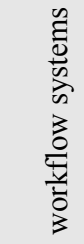 & 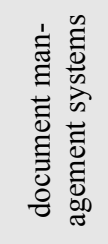 & 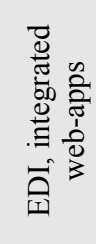 \\
\hline recording problems & $\mathrm{S}$ & $\mathrm{S}$ & $\mathrm{S}$ & $\mathrm{I}$ & E & E & E & $\mathrm{E}$ \\
\hline informal meetings & $\mathrm{S}$ & $\mathrm{S}$ & $\mathrm{S}$ & $\mathrm{I}$ & E & $\mathrm{E}$ & E & $\mathrm{E}$ \\
\hline $\begin{array}{l}\text { joint problem- } \\
\text { solving meetings }\end{array}$ & $\mathrm{S}$ & $S$ & $S$ & I & E & E & E & $\mathrm{E}$ \\
\hline brainstorming & $\mathrm{S}$ & $\mathrm{S}$ & $\mathrm{S}$ & I & E & E & E & E \\
\hline $\begin{array}{l}\text { structured problem- } \\
\text { solving techniques } \\
\text { (e.g. FFA, DMAIC) }\end{array}$ & C & C & $\mathrm{C}$ & $\mathrm{C}$ & $\mathrm{C}$ & $\mathrm{C}$ & $\mathrm{C}$ & $\mathrm{C}$ \\
\hline $\begin{array}{l}\text { documenting solu- } \\
\text { tions }\end{array}$ & E & E & E & E & $\mathrm{C} / \mathrm{E}$ & $\mathrm{C} / \mathrm{E}$ & $\mathrm{C} / \mathrm{E}$ & $\mathrm{C} / \mathrm{E}$ \\
\hline $\begin{array}{l}\text { sharing solutions } \\
\text { within the company }\end{array}$ & $\mathrm{I} / \mathrm{C}$ & $\mathrm{I} / \mathrm{C}$ & $\mathrm{I} / \mathrm{C}$ & $\mathrm{I} / \mathrm{C}$ & $\mathrm{I} / \mathrm{C}$ & $\mathrm{I} / \mathrm{C}$ & $\mathrm{I} / \mathrm{C}$ & $\mathrm{I} / \mathrm{C}$ \\
\hline $\begin{array}{l}\text { sharing solutions } \\
\text { with external part- } \\
\text { ners }\end{array}$ & $\mathrm{I} / \mathrm{C}$ & $\mathrm{I} / \mathrm{C}$ & $\mathrm{I} / \mathrm{C}$ & $\mathrm{I} / \mathrm{C}$ & $\mathrm{I} / \mathrm{C}$ & $\mathrm{I} / \mathrm{C}$ & $\mathrm{I} / \mathrm{C}$ & $\mathrm{I} / \mathrm{C}$ \\
\hline
\end{tabular}

Note: S, E, C, and I denote socialization, externalization, combination and internalization, respectively.

Source: authors.

are also used, then it is defined as "Externalization". The list of ICT tools and systems specified in our questionnaire are summarized in the previous section as well.

Two interviews have been conducted: one of the companies is from the automotive suppliers' sector, while the other one is from the IT service industry. The former is part of a multinational industrial company while the latter is part of a Hungarian group of companies. As for the five key supply chain processes, both companies work together with their suppliers and customers to solve problems related to their day-to-day operations. Meetings in person and teleconferences are supported at both companies with shared screens, workflow and document management systems. The new product development process is more inwardly focused in the case of the automotive supplier, while more customer/supplier focused at the IT services company. Both companies use document management systems in addition to in-person meetings, teleconferences and video-conferences (i.e. only applied by the IT services company) and computer screen sharing, 
to support this process. The technology transfer process is supported by shared drives and document management systems. The supplier performance review process is somewhat less structured in both companies. E-mail, document management systems and shared drives are used in both companies in addition to face-to-face interactions. Finally, the process around exploring new business opportunities and pursuing new contracts involves suppliers and business partners only in the case of the IT services company. The process is supported with document management systems and shared drives.

In summary, both companies interviewed use a wide range of ICT tools and systems to support the processes that require knowledge sharing and creation jointly with their business partners. These tools and systems include various email, file and database server applications, document management, workflow and social media systems either as "in-house" or "cloud based". In addition, project management systems are also applied in both companies to support project based processes. The "Socialization" phase of the SECI model is supported with teleconferences, sharing of computer screens and partially with video-conferencing facilities. Both companies have social network systems at their companies, but whether these are used in communicating with external business partners has not yet been studied. The "Externalization" phase was prevalent during the problemsolving process and was supported with workflow systems, shared drives and integrated systems to identify the problems as they come up. The "Combination" phase was supported by a wide range of ICT tools in both companies: shared drives, document management systems and workflow systems played a key role in procuring problem solving records, test protocols and specifications. Finally, the "internalization" phase was mainly supported by sharing computer screens in addition to teleconferences. However, although the applied ICT solutions are similar, the knowledge creation patterns show some differences, especially if these are compared with the SECI knowledge creation model. In the case of the IT services company, the knowledge creation pattern analysis had the following results:

1) "solving problems as part of the day-to-day operations" process uses all of the knowledge creation phases (socialization, externalization, combination and internalization), but not intensively;

2) the process "developing new products and services" uses all of the knowledge creation phases (socialization, externalization, combination and internalization) like the previous process, but more intensively;

3) the "technology transfer of new products or processes to suppliers or customers" process mainly applies combinations and in a less intensive way also socialization, but did not utilize internalization; 
4) the "reviewing supplier performance" process employs externalization and combinations, but does not apply socialization;

5) the "exploring new business opportunities" process applies mainly combinations and in a less intensive way socialization.

The knowledge creation practice is similar in the "technology transfer of new products or processes to suppliers or customers" and "exploring new business opportunities" processes. The internalization process is not emphasized, which means that the knowledge created in these processes will not be included in the organizational knowledge bases or memory. "Solving problems as part of the day-to-day operation" and "developing new products and services" processes are balanced ones: all of the knowledge creation phases are applied. "Reviewing the supplier performance" process that does not utilize socialization, and extension of their knowledge creation practice with this process would be advisable.

In the case of the other company (a supplier from the automotive sector), the knowledge creation pattern analysis had the following results:

1) the "solving problems as part of the day-to-day operations" process uses all knowledge creation phases (socialization, externalization, combinations and internalization);

2) the "developing new products and services" process uses only socialization, externalization and combination;

3) the "technology transfer of new products or processes to suppliers or customers" process applies mainly socialization and combination, but it does not utilize internalization;

4) the "reviewing supplier performance" process employs mainly combinations, and externalization (in a less intensive way), but does not apply socialization;

5) the "exploring new business opportunities" process was not relevant in this company.

This company applies all knowledge creation processes only in the "solving problems as part of the day-to-day operations" process. Internalization is not emphasized like in the case of the IT service company, which means that the knowledge created in these processes will not be included in the organizational knowledge bases or memory. The "reviewing supplier performance" process does not utilize socialization, and extension of their knowledge creation practice with these phases would be advisable.

In our case, the IT service company exploits the knowledge creation processes to a greater degree, but there is room for improvement and for an enrichment of these processes in respect to both companies. Utilization of socialization could increase the effectiveness of "reviewing supplier performance" processes in both cases. The companies did not focus on the externalization and internalization 
processes sufficiently, so the knowledge which they created in the supply chain processes will not enrich the organizational memory.

\section{CONCLUSIONS}

The goal of our paper was to study how knowledge is created in supply chains and what the key ICT solutions and their role in these processes are. Companies operating in the Székesfehérvár region of Hungary provided the empirical background. Literature on the role of ICT solutions in knowledge management (KM) is extensive, however, the majority of the papers discuss only specific narrow areas of the field, such as knowledge management systems per se. We studied $50+$ research projects on the ICT support of knowledge functions, and found that a considerable number of studies on the application of ICT tools in knowledge sharing and transfer have reported promising findings, but no evidence is provided concerning the role of ICT tools in knowledge creation. The literature review showed that not only the supporting role of knowledge management systems, but that the role of supply chain management systems in knowledge creation should also be studied. We formulated the following research questions:

1) What are the knowledge creation patterns in a supply chain (in the Székesfehérvár region of Hungary)?

2) What are the main ICT solutions applied in the supply chain and what is their role in knowledge creation and collaboration with suppliers and customers?

In order to answer the research questions the most decisive model of the knowledge creation field (SECI by Nonaka and Takeuchi 1995) was adopted in our research model. In the next phase the conceptual model of the research was set up, which was followed by the development of a structured questionnaire that provided the bases for collecting data from selected companies for validation purposes.

This paper makes two main contributions. The first one is that we studied the knowledge creation patterns in three dimensions: the SECI framework, the supply chain processes and ICT solutions, which is a unique approach, compared with the knowledge creation frameworks from the relevant literature. ICT solutions combined with activities in the key supply chain processes determine certain knowledge creation patterns, socialization, externalization, combinations and internalization. In this way the research model can identify the decisive knowledge creation patterns in certain supply chain processes, while information on the applied ICT tool is also provided. The second contribution is that the knowledge creation practice of the companies in terms of the SECI framework is different from the Nonaka and Takeuchi's results. In Nonaka and Takeuchi's cases, the 
companies applied every process (Socialization - Externalization - Combination - Internalization) from the SECI model, while in our cases the typical knowledge creation patterns were different. Internalization is not utilized as it could be, so the related knowledge will not be integrated into the organizational knowledge bases. Section five details the knowledge creation patterns in a supply chain of the studied companies, which provides the answer to the first research question. It is surprising that the IT service company looks more socialization oriented than the other one. Socialization is stressed in the "developing new products and services" process and applied in the "exploring new business opportunities" process in the case of the IT service company. Section five provides an overview about the main ICT solutions applied in the supply chain and their role in knowledge creation and collaboration with suppliers and customers. We did not find substantial differences between the studied companies in terms of the ICT solutions, which they apply in the supply chain. Both companies use document management and workflow systems, project management and business intelligence solutions (reporting, dashboard). The IT service company applies data warehouse/data mart, while the company from the automotive suppliers' sector employs IoT, predictive analytics and social media solutions as well.

The conceptual framework, which we defined, can be used for the evaluation of knowledge creation patterns in a company and facilitates the identification of knowledge creation gaps. Our approach to knowledge creation analysis could be used to compare the knowledge creation processes of companies. Further research in this field could be focused on a more detailed analysis of our knowledge creation framework in the Székesfehérvár region. The next phase of the research could also support knowledge pattern maturity model development.

\section{REFERENCES}

Bellantuono, N. - Pontrandolfo, P. - Scozzi, B. (2013a): Different Practices for Open Innovation: A Context-Based Approach. Journal of Knowledge Management 17(4): 558-568.

Bellantuono, N. - Pontrandolfo, P. - Scozzi, B. (2013b): Mapping the Knowledge Supply Chain to Foster Innovation. International Journal of Information Systems and Social Change 4(4): 9-25.

Bessant, J. - Kaplinsky, R. - Lamming, R. (2003): Putting Supply Chain Learning into Practice. International Journal of Operations \& Production Management 23(2): 167-184.

Carlsson, S. A. (2003): Knowledge Managing and Knowledge Management Systems in InterOrganizational Networks. Knowledge and process management 10(3): 194-206.

Choon Tan, K. (2001): A Framework of Supply Chain Management Literature. European Journal of Purchasing \& Supply Management 7(1): 39-48.

Cooper, M. C. - Lambert, D. M. - Pagh, J. D. (1997): Supply Chain Management: More Than a New Name for Logistics. The International Journal of Logistics Management 8(1): 1-14. 
Corso, M. - Paolucci, E. (2001): Fostering Innovation and Knowledge Transfer in Product Development through Information Technology. International Journal of Technology Management 22(1-3): 126-148.

Dyer, J. H. - Nobeoka, K. (2000): Creating and Managing a High-Performance Knowledge-Sharing Network: The Toyota Case. Strategic Management Journal 21(3): 345-367.

Garavelli, A. C. - Gorgoglione, M. - Scozzi, B. (2002): Managing Knowledge Transfer by Knowledge Technologies. Technovation 22(5): 269-279.

Garcia-Muniz, A. S. - Vicente, M. R. (2014): ICT Technologies in Europe: A Study of Technological Diffusion and Economic Growth under Network Theory. Telecommunications Policy 38(4): $360-370$.

Gillani, S. - Kö, A. (2016): ProMine: A Text Mining Solution for Concept Extraction and Filtering. In: Gábor, A. - Kö, A. (ed.): Corporate Knowledge Discovery and Organizational Learning: The Role, Importance, and Application of Semantic Business Process Management. Berlin: Springer.

Halley, A. - Beaulieu, M. (2005): Knowledge Management Practices in the Context of Supply Chain Integration: The Canadian Experience. Supply Chain Forum: An International Journal 6(1): 66-81.

Hendriks, P. (1999): Why Share Knowledge? The Influence of ICT on the Motivation for Knowledge Sharing. Knowledge and Process Management 6(2): 91-100.

Jashapara, A. (2004): Knowledge Management an Integral Approach. London: Pearson Education.

Kö, A. - Fehér, P. - Varga, K. (2010): Role of ICT in Knowledge Networks among EU SMEs. Proceedings of the 5th International Conference on Software, Knowledge Information, Industrial Management and Applications (SKIMA).

Kö, A. - Gábor, A. - Vas, R. - Szabó, I. (2008): Ontology-Based Support of Knowledge Evaluation in Higher Education. Proceedings of the 2008 Conference on Information Modelling and Knowledge Bases.

Lee, Z. - Lee, J. (2000): An ERP Implementation Case Study from a Knowledge Transfer Perspective. Journal of Information Technology 15(4): 281-288.

Lopez-Nicolas, C. - Soto-Acosta, P. (2010): Analyzing ICT Adoption and Use Effects on Knowledge Creation: An Empirical Investigation in SMEs. International Journal of Information Management 30(6): 521-528.

Maier, R. (2007): Knowledge Management Systems: Information and Communication Technologies for Knowledge Management. Berlin: Springer

Marra, M. - Ho, W. - Edwards, J. S. (2012): Supply Chain Knowledge Management: A Literature Review. Expert Systems with Applications 39(5): 6103-6110.

Mentzer, J. J. T. - DeWitt, W. - Keebler, J. S. - Min, S. - Nix, N. W. - Smith, C. D. - Zacharia, Z. G. (2001): Defining Supply Chain Management. Journal of Business Logistics 22(2): 1-25.

Nelissen, P. - Wenneker, M. - van Selm, M. (2008): ICT Performance in Processes of Knowledge Sharing in Organizations: A Review of Literature. Communications 33(1): 91-107.

Nonaka, I. - Lewin, A. Y. (1994): Dynamic Theory Knowledge of Organizational Creation. Organization Science 5(1):14-37.

Nonaka, I. - Takeuchi, H. (1995): Knowledge-Creating Company. New York: Oxford University Press.

Okunoye, A. - Karsten, H. (2002): ITI as Enabler of Knowledge Management: Empirical Perspective from Research Organisations in Sub-Saharan Africa. Proceedings of the Annual Hawaii International Conference on System Sciences.

Polanyi, M. (1967): The Tacit Dimension. New York: Garden City. 
Retzer, S. (2010): Inter-Organisational Knowledge Transfer among Research and Development Organisations: Implications for Information and Communication Technology Support. PhD Dissertation. New Zeland.

Samuel, K. E. - Goury, M. L. - Gunasekaran, A. - Spalanzani, A. (2011): Knowledge Management in Supply Chain: An Empirical Study from France. The Journal of Strategic Information Systems 20(3): 283-306.

Spence, P. (2005): Knowledge Networking on a National Scale: A New Zealand Case Study. In: Rao, M. (ed.): Knowledge Management Tools and Techniques. Oxford: Elsevier.

Stock, J. R. - Boyer, S. L. (2009): Developing a Consensus Definition of Supply Chain Management: A Qualitative Study. International Journal of Physical Distribution \& Logistics Management 39(8): 690-711.

Subashini, R. - Rita, S. - Vivek, M. (2012): The Role of ICTs in Knowledge Management (KM) for Organizational Effectiveness. In: Krishna P.V. - Babu M.R. - Ariwa E. (eds): Global Trends in Information Systems and Software Applications. Communications in Computer and Information Science. Berlin: Springer.

Swan, J. - Newell, S. - Scarbrough, H. - Hislop, D. (1999): Knowledge Management and Innovation: Networks and Networking. Journal of Knowledge Management 3(4): 262-275.

Szász, L. - Scherrer, M. - Deflorin, P. - Sevrani, K. - Cico, B. - Besimi, A. - Rácz, B. (2017): The Role of ICT-Based Information Systems in Knowledge Transfer within Multinational Companies. Proceedings of IFIP International Conference on Advances in Production Management Systems.

Templeton, G. F. - Lewis, B. R. - Snyder, C. A. (2002): Development of a Measure for the Organizational Learning Construct. Journal of Management Information Systems 19(2): 175-218.

Uriarte, F. A. J. (2008): Introduction to Knowledge Management. Jakarta: ASEAN Foundation.

Vipinkumar, V. P. - Athira, P. V. - Mini, K. G. (2013): Role of ICT in Knowledge Management. Kochi: Central Marine Fisheries Research Institute.

Wagner, S. M. - Bukó, C. (2005): An Empirical Investigation of Knowledge-Sharing in Networks. Journal of Supply Chain Management 41(4): 17-31.

Open Access. This is an open-access article distributed under the terms of the Creative Commons Attribution 4.0 International License (https:/creativecommons.org/licenses/ by/4.0), which permits unrestricted use, distribution, and reproduction in any medium, provided the original author and source are credited, a link to the CC License is provided, and changes - if any - are indicated. (SID_1) 